\title{
Transpositions of Function Concept in Mathematics Curricula and Textbooks from the Historical Development Perspective
}

\author{
Mustafa Gök
}

Dr., Yüzüncü Yı1 Üniversitesi, Turkey, mustafagok@yyu.edu.tr

\author{
Abdulkadir Erdoğan \\ Assoc. Prof., Anadolu University, Turkey, abdulkadirerdogan@anadolu.edu.tr \\ Emel Özdemir Erdoğan \\ Assoc. Prof., Anadolu University, Turkey, eoerdogan@anadolu.edu.tr
}

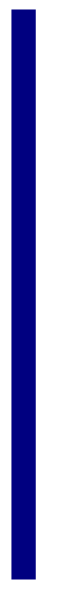
In the historical process, scientific knowledge is constantly changing and developing. Concepts in curricula and textbooks are also affected by these changes and developments. The function concept is a typical example of this situation. The concept of function gained different meanings in different historical contexts although no clear information was found about the evolution of the concept in curricula and textbooks in Turkey. The purpose of this study is to examine the transposition of function concept in secondary school mathematics curricula and textbooks in Turkey from the perspective of the historical development of the concept from the declaration of the Republic of Turkey until today. In the study, document analysis, which is a qualitative research method, was used. Secondary school mathematics curricula and textbooks, which were entered into force in Turkey from 1924 until 2017, were examined. The findings of the study show that the function concept in mathematics curricula passed through three basic periods: the Eulerian period (1924-1952), the Dirichletian period (1952-1974) and the Bourbakist period (1974-2017).

Keywords: curriculum, textbooks, function concept, didactic transposition, historical perspective

\section{INTRODUCTION}

Mathematical concepts should not be perceived as absolute and fixed objects which have completed their development (Erdoğan, 2009). Mathematical concepts often arise in the context of a problem, defined by mathematicians based on this context but they gain new meanings over time in different contexts (Cajori, 1919; Erdoğan, 2009, Merzbach \& Boyer, 2011). In this way, mathematical concepts are continuing their 
development in a dynamic process. The development of the function concept is the most typical example of this. The roots of the function concept extend to Babylon tablets (Kleiner, 1989) and function concept first appeared on the stage of history in the form of a table of values summarizing the observed natural phenomena (Kline, 1972). The concept, which was used in this way intuitively for a long time, was qualified as a curved line of a motion in the 17th century and as an analytical expression, that is, the relationship between two variables in the 18th century, parallel to the studies carried out for the development of algebraic symbolism and for solving some mathematics and physics problems in the coordinate plane (Kleiner, 1993). Later at the beginning of the 20th century, as a result of the effect of set theory and the studies of Bourbaki school, it was defined as a univalent correspondence between two sets (Even, 1993). Siu (1994) categorized the meanings of function concept in the historical development process into three as static, kinematic / geometric and algebraic.

- Static meaning: The meaning such as table of values, correspondence, ordered pairs and morphism, which developed early at the emergence of the concept or in the $20^{\text {th }}$ century under the influence of set theory.

- Kinematic or geometric meaning: The meaning which developed with the studies where the concept is used to represent the curve of a motion, where discontinuous ${ }^{1}$ functions and mapping were at the forefront.

- Algebraic meaning: The meaning which developed in the context of continuous functions, series, analytical expressions and representations.

In the historical development process, many mathematicians contributed to the development of the concept and gave definitions containing one or more of the above meanings (Kleiner, 1989; 1993; Ponte, 1992; Usiskin et al., 2003). Highlights from these definitions are summarized in Table 1 by Cha (1999).

Table 1

Definitions of Mathematicians on Function Concept (Cha, 1999, pp. 38-39)

\begin{tabular}{lll}
\hline Year & Mathematician & Definition \\
\hline 1665 & Newton & Any relationship between variables. \\
\hline 1667 & Gregory & $\begin{array}{l}\text { A quantity obtained from other quantities by a succession of algebraic operations or by any other } \\
\text { operation imaginable. }\end{array}$ \\
\hline 1673 & Leibniz & Any quantity varying from point to point of curve. \\
\hline 1697 & Bernoulli & Quantities formed using algebraic and transcendental expressions of variables and of constants. \\
\hline 1714 & Leibniz & Quantities that depend on a variable. \\
\hline 1718 & Bernoulli & $\begin{array}{l}\text { Function of a certain variable [as] a quantity that is composed in some way from that variable and } \\
\text { constants. }\end{array}$ \\
\hline 1748 & Euler & $\begin{array}{l}\text { Formula } \text { or analytic expression composed in any manner from that variable quantity and numbers or } \\
\text { constant quantities representing the relation between variables. }\end{array}$ \\
\hline 1755 & Euler & $\begin{array}{l}\text { If } x \text { denotes a variable quantity then all the quantities, which depend on } x \text { in any manner whatever or } \\
\text { are determined by it are called its functions. If some quantities } \text { depend on others in such a way that if } \\
\text { the latter are changed the former undergo changes themselves then the former quantities are called } \\
\text { functions of the latter quantities. }\end{array}$
\end{tabular}

\footnotetext{
${ }^{1}$ Although the $1 / \mathrm{x}$ function is discontinuous at $\mathrm{x}=0$, Euler early considered it as continuous (Lutzen, 1983).
} 


\begin{tabular}{lll}
\hline 1797 & Lagrange & Any expression useful for calculation in which these variables enter in any manner whatsoever. \\
\hline 1806 & Lagrange & $\begin{array}{l}\text { A combination of operations that must be performed on known quantities to obtain the values of } \\
\text { unknown quantities, and that the latter are properly only the last result of the calculation. }\end{array}$ \\
\hline 1829 & Dirichlet & $\begin{array}{l}y \text { is a function of a variable } x \text {, defined on the interval } a<x<b, \text { if to every value of the variable } x \text { in } \\
\text { this interval there corresponds a definite value } y \text {. Also, it is irrelevant in what way this } \\
\text { correspondence is established. }\end{array}$ \\
\hline 1917 & Caratherdory & A rule of correspondence from a set A to real numbers. \\
\hline 1939 & Bourbaki & A rule of correspondence between two sets. \\
\hline 1939 & Bourbaki & $\begin{array}{l}\text { Let } E \text { and } F \text { be two sets, which may or may not be distinct. A relation between a variable element } x \text { of } \\
E \text { and a variable element } y \text { of } F \text { is called a functional relation in } y \text { if, for all } x \text { in } E \text {, there exists a } \\
\text { unique } y \text { in } F, \text { which is in the given relation with } x .\end{array}$ \\
\hline 1950 & $\begin{array}{l}\text { Dirichlet- } \\
\text { Bourbaki }\end{array}$ & $\begin{array}{l}\text { Any correspondence between two sets which assigns to every element in the domain exactly one } \\
\text { element in the range. }\end{array}$
\end{tabular}

As seen in Table 1, mathematicians often defined function concept related to the developments in sciences and to the fields they had been working on (Even, 1993). For example, in Leibniz's first definition, parallel to his work, which contributed immensely to the development of calculus, the geometric meaning of the concept comes to the forefront but in the definitions of Euler who contributed to many areas of mathematics, algebraic meaning is dominant. On the other hand, Table 1 shows that many mathematicians revised their definition of function concept over time. This indicates that there is a continuous change in the definition of function concept as an object of scientific knowledge. Drawing attention to this issue, Cha (1999), stated that function concept was defined as a quantity, process, formula, expression or relationship by the 17 th and 18th century mathematicians but as a univalent correspondence by the 19th and 20th century mathematicians. Along with these definitions, a new definition, which emphasize the process dimension of the concept, have appeared in recent years as "A dynamic process (a mechanism) which transforms inputs into outputs is called a function (Usiskin et al., 2003)".

Function is a fundamental concept in terms of both mathematics and mathematics teaching (Kleiner, 1993; Oehrtman, Carlson \& Thompson, 2008; Ponte, 1992; Sajka, 2003). The concept which developed as the fundamental element of calculus in the beginning has become an indispensable concept for many areas such as advanced calculus, functional analysis, algebra, etc. with the power of the set concept in the definition given by the Bourbaki school. In terms of teaching mathematics, function concept has great importance and plays a central and unifying role between concepts (Selden \& Selden, 1992).

With the didactic transposition theory (Chevallard, 1985), the examination of the development process of mathematical concepts, relations between concepts, and the changes observed in mathematical concepts affected by their use in different contexts (e.g. school mathematics) have become more systematic. In this sense, while mathematical concepts are included in mathematics curricula, while the content is prepared in the textbooks in accordance with the expectations of the curriculum, while teachers are preparing their teaching content using textbooks and other resources, and while the students is learning the subjects taught to them, it is known that the concepts pass through a number of changes. Examining these changes has major implications for understanding and interpreting educational reforms, curricula, and the differences between what is aimed to be taught and what is actually learned (Bosch, \& Gascón, 
2006). Thus, the question of how the function concept, which has a long historical process giving it various meanings and definitions and which is one of the basic concepts for mathematics and mathematics education, has found a place in curricula, in what meanings it has used in mathematics curricula and textbooks, and how its meanings have changed over time appear to be important.

\section{Functions in Mathematics Curricula and Textbooks}

The idea that the function concept should be included in mathematics curricula seems to start to be discussed in international mathematics conferences since the last quarter of the 19th century. The first step was taken in this regard by the German Professor Felix Klein (Breslich, 1932; Hamley, 1934; Hedrick, 1938). In this direction, many countries in Europe and America started to teach the function concept from the beginning of the 20th century (Denbel, 2015; Hamley, 1934). In mathematics curricula, the function concept was initially included in a similar meaning to the definition of Euler and with the "new mathematics" reform, definitions close to the definition of Bourbaki has begun to take place in many countries (Denbel, 2015). However, it was soon understood that the meaning of the Bourbaki's definition, which was quite productive for mathematics, was quite abstract and had great difficulties for students to perceive (Malik, 1980; Markovits et al., 1986; Tall \& Bakar, 1992; Eisenberg, 2002). However, this definition could not be easily abandoned in mathematics teaching. Kennedy and Ragan (1969) stated that until 1959, in basic algebra and university algebra textbooks in America, function concept was defined as rules or correspondences between variables and between 1959 and 1969, it was used as a definition involving sets of ordered pairs. Cooney and Wilson (1993) found that in 16 secondary school mathematics textbooks which were published in America between 1958 and 1986, function concept was defined either as a set of ordered pairs or as a correspondence between elements of two sets. A few studies examining the development of concepts in secondary school mathematics curricula in Turkey have carried out. Curriculum studies have mostly focused on a short history of mathematics education or on a general comparison of curricula in the context of change (Argün et al., 2010; Zeybek, 2012). On the other hand, some studies have addressed the comparison between countries (Güzel, Karataş \& Çetinkaya, 2010) and teachers' opinions about the overall or a single component of the curriculum (Merter \& Şan, 2012; Tuncel, 2015). No study has been found on how one of the mathematical concepts, especially the function concept, has been included in mathematics teaching through historical process. In this study, the question of how the function concept has taken place in mathematics curricula and textbooks, which were published from the first years of the republic to the present day in Turkey, is examined from the historical development perspective of the concept. In this purpose, the following research questions were investigated:

- When the function concept was first included in mathematics curricula?

- What meaning of the concept in what period of time has found a place in mathematics curricula and textbooks? 
- What are the subjects, concepts and their relations in mathematics curricula and textbooks in which the function concept has been involved?

\section{METHOD}

The Model of the Study

In this study, document analysis, which is one of the qualitative research methods, was used. The document analysis includes an analysis of materials that contain information about the phenomenon or phenomena targeted to be examined. In qualitative research, document analysis can be a stand-alone data collection method as well as it can be used with other data collection methods (Yıldırım \& Şimşek, 2011).

\section{Collection of Documents}

In this study, secondary school mathematics curricula from 1924 to 2017 were examined in the context of the function concept. These curricula were chronologically published in 1924, 1927, 1931, 1934, 1938, 1949, 1952, 1956, 1957, 1960, 1970, 1974, 1987, 1998, 2005, 2013 and 2017. Also, in this study, 17 mathematics textbooks were examined to reflect these processes to a large extent. These textbooks are given in table 2 .

Table 2

Textbooks examined in the study

\begin{tabular}{lll}
\hline Year & Author(s) & Textbook \\
\hline 1931 & Hikmet & High school books Class III: Algebra \\
\hline 1938 & Commission & High school books: Arithmetic and Algebra I \\
\hline 1939 & Commission & High school books: Arithmetic and Algebra I \\
\hline 1953 & Bener \& Aslantürk & Teacher high schools books: Arithmetic and Algebra I \\
\hline 1963 & Aslantürk & High school books: Algebra I \\
\hline 1967 & Taner, Özer, \& Demirtaş & Basic mathematics I \\
\hline 1984 & Gürdal, Aydan, \& Metin & Mathematics high school I (Second Edition) \\
\hline 1987 & Gürdal, Aydan, \& Metin & Mathematics high school I (Fourth Edition) \\
\hline 1999 & Gürdal, Aydan, \& Metin & Mathematics high school I (Seventh Edition) \\
\hline 2001 & Çetiner, Yıldı, Yıldı Kavcar & High School 1 mathematics textbook (Second Edition). \\
\hline 2005 & Çetiner, Yıldır \& Kavcar & High School 1 mathematics textbook (Fourth Edition). \\
\hline 2012 & Alkan (Ed) & High School 1 mathematics textbook (Third Edition). \\
\hline 2012 & Aytar \& Arslantaş & The 9th grade mathematics textbook in secondary school \\
\hline 2013 & Commission & Secondary school mathematics 9th grade course book \\
\hline 2013 & Karakuyu \& Bağc1 & Secondary School Mathematics 9th grade second book \\
\hline 2015 & Gökbaş, Kaleci \& Mutluoğlu & Secondary School Grade 9 Mathematics Textbook \\
\hline
\end{tabular}

In the data collection process, all of the mathematics curricula from 1924 to 2017 were obtained. On the other hand, two steps were used to determine mathematics textbooks to be analysed. Firstly, accessible textbooks from 1928 to 2017 were obtained. Textbooks published until 1931 could not be reached because of the change in written language. (The alphabet revolution was made on 1 November 1928.) Therefore, it is not known how the concept of function was included in the textbooks reflecting the 1924 and 1927 curriculum. However, considering that the concept of function was not included in the curricula of this period, it is assumed that there was no radical change in the teaching of 
function concept in the textbooks. In addition, the textbook prepared according to the 1931 curriculum and published in the new language has been reached and examined within the scope of the research. Secondly, the textbooks which reflect a curricular change related to function concept were determined.

Mathematics curricula and textbooks examined in the scope of the study were obtained from Ministry of Education Journal of Announcement, http://mufredat.meb.gov.tr/ internet site prepared by the Ministry of Education Head Council of Education and Morality, Ferit Ragip Tuncor Ministry and Archives Documentation Library established within the scope of National Education Support Services Directorate and from the book of Zeybek (2012) titled Development of Mathematics Curricula (1924-2011).

\section{Analysis of the Documents}

In the study, objectives, behaviours, acquisitions, explanations and definitions related to function concept in mathematics curricula and textbooks were examined. In addition, it was attempted to determine related subjects and concepts introduced before functions in order to better identify in what context and meaning the function concept was used.

Contents determined in curricula and textbooks were descriptively analysed. Definitions determined in the contents were classified according to the definitions given by Cha (1999). The different meanings of the functions were determined in terms of static, geometric and algebraic meanings according to the themes revealed in the study of Siu (1994).

\section{Reliability and Validity of the Analyses}

Collected data (curricula and textbooks) were primary sources. The definitions of function concept given in these sources were quoted in findings as given in the sources. Data were analysed by three researchers according to different meaning of the concept and the definitions of the concept given by mathematicians, which determined themes for the analyses. It was seen that there was a complete agreement among the researchers in the use of the concept in different meanings (static, geometric, algebraic). However, a difference was emerged, in two cases, when the definition given in curricula and textbooks were tried to be classified according to the definition given by mathematicians. The first case was with the textbook written by Bener and Aslantürk (1953) where the question was if the definition used was similar to the definition of Euler or to the definition of Dirichlet. The second case was with the 2005 curriculum where the question was if the definition used was similar to the definition of Bourbaki or to the definition of Drichlet-Bourbaki. In these situations, an agreement was found following a process of long discussions and comments on the meanings of the definitions.

\section{FINDINGS}

The analysis of the curricula and textbooks showed that the function concepts passed through three periods: 1924-1952, 1952-1974 and 1974-2017. These periods were determined by taking into account the curricular changes in which significant changes in the teaching of the concept were identified. 


\section{Function Concept in 1924-1952 Period}

Between 1924 and 1931, mathematical subjects were found under more than one course (algebra, geometry, theoretical calculations, trigonometry, mechanics, astronomy) in curricula and since 1931, these courses were gathered under mathematics (formerly known as riyaziye). In the 1938 curriculum change, the name of the course became mathematics (in modern language) and sub-learning areas were defined as algebra, geometry, astronomy. In general, in 1924-1952 period, changes focused on updating the names, the durations and the contents of the courses. From the 1924 curriculum to 1949 curriculum, no definition of the function concept was found. Nevertheless, it appears that the curricula included objectives on linear, trigonometric, logarithmic, and exponential functions. For example, in the 1934 curriculum, in first grade, examination of $y=a x+b$ function and its graphic representation and, in third grade, functions like $y=a x^{4}+b x^{2}+c, \quad y=(a x+b) /\left(a x^{\prime}+b\right)$ and their representation were found among the acquisitions. The function concept appears as a combination of algebraic and geometric approaches in these acquisitions. The place of the concept in the textbooks of the period is given in table 3.

Table 3

Function Concept in 1924-1952 Period Textbooks

\begin{tabular}{|c|c|c|c|}
\hline $\begin{array}{l}\text { Textbook } \\
\text { (Grade) }\end{array}$ & $\begin{array}{l}\text { Author(s) \& } \\
\text { Year }\end{array}$ & Pre-Functional Topics and Function Definition & $\begin{array}{l}\text { Definition \& } \\
\text { meaning }\end{array}$ \\
\hline Algebra III & $\begin{array}{l}\text { Hikmet, } \\
1931\end{array}$ & $\begin{array}{l}\text { Numbers } \rightarrow \text { Equations } \rightarrow \text { Inequalities } \rightarrow \text { Functions } \\
\text { If two kinds of quantities exist and if different values of } \\
\text { one are dependent to the values that the other can take, } \\
\text { the first quantity is called the function of the other. } \\
\text { [Function definition] For example, let us consider the } \\
5 x-9 \text { algebraic expression ... } \\
\text { Let us take into account the ax+b binary term where a } \\
\text { and b are fixed quantities and } x \text { is a transformation. } \\
\text { This expression is a function of } x \text { [Function definition]. }\end{array}$ & $\begin{array}{l}\text { Algebraic } \\
\text { meaning } \\
\text { Euler's } \\
\text { definition }\end{array}$ \\
\hline $\begin{array}{l}\text { Arithmetic } \\
\text { and } \\
\text { Algebra I }\end{array}$ & $\begin{array}{l}\text { Commission1 } \\
938 ; \\
1939\end{array}$ & $\begin{array}{l}\text { Numbers } \rightarrow \text { Arithmetic } \rightarrow \text { Multiplication } \rightarrow \text { Division } \\
\text { (Fractions) } \rightarrow \text { Problems } \rightarrow \text { Ratio-proportion } \rightarrow \text { First } \\
\text { degree equations with two or several unknowns } \rightarrow \\
\text { Graphical representation Example } 1 \text { : The fever of a } \\
\text { person who has typhoid disease is measured every day } \\
\text { at } 6 \text { o'clock and } 18 \text { o'clock and the following table } \\
\text { results are obtained ... } \\
\text { Ascending Line: Draw a right triangle with a vertical } \\
\text { edge double of the other. } \\
\text { If the small vertical edge of the triangle is indicated by } \\
x \text { and the large one by y, between these two edges there } \\
\text { is y=2x relation. Since each value of x corresponds } \\
\text { exactly to a certain value of y, y is a task of x } \\
\text { [Definition of function] ...In general: If the equation of } \\
\text { the line is } y=m x, \text { then for each point y:x ratio equals to } \\
\text { (m). The task y=mx is a task that demonstrates the } \\
\text { smooth and equal increasing we encounter in our } \\
\text { everyday life. [Explanation of function concept] }\end{array}$ & $\begin{array}{l}\text { Geometric } \\
\text { and algebraic } \\
\text { meaning } \\
\text { Euler's } \\
\text { definition }\end{array}$ \\
\hline
\end{tabular}

In Table 3, it is seen that the function concept was built in the textbooks of this period on the subjects of algebra such as numbers, ratio-proportion, equation. In this period, 
although the definition of function was not given formally in the high school first grade textbooks, the concept was tried to be explained intuitively through examples of daily life. Here, the emphasis on the graph draws attention. On the other hand, in the textbook of third grade of high school, it appears that the function concept was defined in a similar way with the definition given by Euler.

\section{Function Concept in 1952-1974 Period}

The first curriculum of this period is the 1952 curriculum in which the definition of the concept was included for the first time and, the last curriculum of this period is the 1974 curriculum which was a curriculum of transition to "new mathematics". Some acquisitions of this period show that formal definition of function concept should take place in mathematics curricula. In Table 4, the acquisitions and explanations related to the function concept are given.

Table 4

Function Concept in 1952-1974 Period Curricula

\begin{tabular}{|c|c|c|c|c|}
\hline Year & Grade & Acquisitions/Behaviours/ Purpose & Explanation & $\begin{array}{l}\text { Definition } \\
\& \text { meaning }\end{array}$ \\
\hline 1952 & 1 & $\begin{array}{l}\text { Concepts of variable and } \\
\text { function; coordinate system in the } \\
\text { plane. Graphical representation } \\
\text { of empirical functions. } \\
\text { Definitions of various functions. }\end{array}$ & - & $\begin{array}{l}\text { Geometric } \\
\text { meaning }\end{array}$ \\
\hline 1956 & 1 & $\begin{array}{l}\text { Concepts of variable and } \\
\text { function; coordinate system in the } \\
\text { plane. Graphical representation of } \\
\text { empirical functions. } \\
\text { Function concept and various } \\
\text { function types. }\end{array}$ & $\begin{array}{l}\text { It should be particularly } \\
\text { emphasized here that } \\
\text { the idea of the function } \\
\text { is graphically } \\
\text { represented on the } \\
\text { coordinate system. }\end{array}$ & $\begin{array}{l}\text { Geometric } \\
\text { meaning }\end{array}$ \\
\hline $\begin{array}{l}1957 \\
1960 \\
1970\end{array}$ & 1 & $\begin{array}{l}\text { Concepts of variable, function, } \\
\text { increasing and decreasing } \\
\text { function. } \\
\text { Function concept and various } \\
\text { function types. }\end{array}$ & $\begin{array}{l}\text { Sketching by point- } \\
\text { point of numerical } \\
\text { functions such as } \\
y=a x+b, y=a x^{2}+b x+c\end{array}$ & $\begin{array}{l}\text { Geometric } \\
\text { meaning }\end{array}$ \\
\hline
\end{tabular}

In Table 4, it is seen that the definition of function concept first entered in the curricula in 1952 with the variable concept in the First Grade. This table also shows that, accompanied by the variable concept, the graphical approach to functions was emphasized. It is not clear from the curricula what kind of definition was adopted for the function concept but the emphasis on variable concept and graph indicate that functions defined on real numbers were to be studied and definitions close to the definition of Dirichlet were adopted. The results of the analyses related to the place of the concept in textbooks of this period are given in Table 5. 
Table 5

The Function Concept in 1952-1974 Period Textbooks

\begin{tabular}{|c|c|c|c|}
\hline $\begin{array}{l}\text { Textbook } \\
\text { (Grade) }\end{array}$ & $\begin{array}{l}\text { Author(s) \& } \\
\text { Year }\end{array}$ & Pre-Functional Topics and Function Definition & $\begin{array}{l}\text { Definition \& } \\
\text { meaning }\end{array}$ \\
\hline $\begin{array}{l}\text { Arithmetic and } \\
\text { Algebra I }\end{array}$ & $\begin{array}{l}\text { Bener \& } \\
\text { Aslantürk, } \\
1953\end{array}$ & $\begin{array}{l}\text { Numbers } \rightarrow \text { Algebraic expressions and operations } \rightarrow \text { First } \\
\text { degree equations and problems } \rightarrow \text { Ratio- } \\
\text { Proportion } \rightarrow \text { First degree equations with two and three } \\
\text { unknown } \rightarrow \text { Variable and Functions } \\
\text { On a given interval, each letter (generally quantities) } \\
\text { which can have various values is called a variable... Let } \\
\text { us consider the } 3 x+5 \text { algebraic expression. If random } \\
\text { numerical values are given to } x \text { here, it can be seen that } \\
\text { expression receives some numerical values in exchange } \\
\text { for these values... In that case, the value of this algebraic } \\
\text { expression depends on the value to be given to } x \text {. In } \\
\text { other words, although } x \text { can be varied freely, the } \\
\text { expression varies depending on } x \text {. Here } x \text { is called an } \\
\text { independent variable and the expression that changes } \\
\text { depending on it is called a function. [Function } \\
\text { definition] This expression written as } \mathrm{f}(\mathrm{x})=3 \mathrm{x}+5 \text { as a } \\
\text { function of } \mathrm{x} . . \text { In mathematics, the function of an } \mathrm{x} \\
\text { variable is denoted by the symbol } \mathrm{f}(\mathrm{x}) \text { or by y. For } \\
\text { example, the first degree binomial ax }+\mathrm{b} \text { is a function of } \\
\text { the variable } \mathrm{x} \text { and it is written as } \mathrm{f}(\mathrm{x})=\mathrm{ax}+\mathrm{b} \text { or } \mathrm{y}=\mathrm{ax}+\mathrm{b} \text {. }\end{array}$ & $\begin{array}{l}\text { Drichlet's } \\
\text { definition }\end{array}$ \\
\hline Algebra I & $\begin{array}{l}\text { Aslantürk, } \\
1963\end{array}$ & $\begin{array}{l}\text { Numbers } \rightarrow \text { Algebraic expressions } \rightarrow \text { Ratio and } \\
\text { proportion } \rightarrow \text { Coordinate system } \rightarrow \text { Variable and } \\
\text { functions } \\
\text { If y takes certain values corresponding to each specific } \\
\text { value of an } x \text { variable, then y is the function of } x \\
\text { [Definition of function]; and it is written as } y=f(x) \text { and } \\
\text { read as "y equals function } x " .\end{array}$ & $\begin{array}{l}\text { Algebraic } \\
\text { meaning }\end{array}$ \\
\hline Algebra III & $\begin{array}{l}\text { Aslantürk, } \\
1963\end{array}$ & $\begin{array}{l}\text { Numbers } \rightarrow \text { Polynomials and factorization } \rightarrow \\
\text { Equations, relations between coefficients and roots } \rightarrow \\
\text { Functions } \\
\text { Let's take two quantities, the value of the one depending } \\
\text { on the value of the other. Let's say y to the one of these } \\
\text { quantities and } x \text { to the other. If the value of } y \text { is } \\
\text { constituted by the value of } x \text { then y quantity is called a } \\
\text { function of } x \text {. [Function definition] ... } \\
\text { After giving the idea of interval, a more precise } \\
\text { definition of the function can be made: Let's consider an } \\
\text { interval (a, b). If each value of } x \text { in this interval } \\
\text { corresponds to a y number, y is called as the function of } \\
x .[\text { Function definition] and it is written as } y=f(x) \text { and } \\
\text { read as y equals function } x \text {. }\end{array}$ & $\begin{array}{l}\text { Algebraic } \\
\text { meaning } \\
\text { Drichlet' } \\
\text { definition }\end{array}$ \\
\hline $\begin{array}{l}\text { Basic } \\
\text { Mathematics } \\
\mathrm{I}^{2}\end{array}$ & $\begin{array}{l}\text { Taner, Özer \& } \\
\text { Demirtaş, } \\
1967\end{array}$ & $\begin{array}{l}\text { Logic } \rightarrow \text { Sets } \rightarrow \text { Relation and Function } \\
\text { Consider A and B sets are given. The f relation from A } \\
\text { to } \mathrm{B} \text {, which assigns each element of A to exactly one } \\
\text { element of } \mathrm{B} \text {, is called as a function from A to B. }\end{array}$ & $\begin{array}{l}\text { Static meaning } \\
\text { Bourbaki's } \\
\text { definition }\end{array}$ \\
\hline
\end{tabular}

${ }^{2}$ This book, which was used for experimental purposes, was adapted from the High School of Science Basic Mathematics I curriculum during the High School of Science Project.

International Journal of Instruction, January2019 • Vol.12, No.1 
Table 5 shows that the most striking change in mathematics textbooks related to function concept was realized in this period. Similar to the previous period, although function concept was built on numbers, ratio-proportion and equations, a more open place was given to the variable concept in this period. It is also clearly seen that the interval concept was formally included in arithmetic and algebra I textbook in 1953 for the first time and it was defined in algebra III textbook in 1963 . Accordingly, it is understood that Dirichlet's definition was adopted in textbooks of this period. However, emphasis on graphics in the curricula of the period was not found in the function definitions of the textbooks. It is observed that the meaning attached to the function concept started to change at the end of this period (Zeybek, 2012, s.161). Table 5 shows that in the textbook used in the High School of Science Project (1960-1967), which was one of the important projects carried out at that time, the function concept was given in the context of logic, sets and relation and it reflects the definition of Bourbaki through arbitrary sets.

\section{Function concept in 1974-2017 Period}

This period starts with the curriculum approved in 1974 and implemented in 1976 (Zeybek, 2012). In Table 6, the acquisitions and explanations related to the function concept in the curricula of the period are given. 
Table 6

Function Concept in 1974-2017 Period Curricula

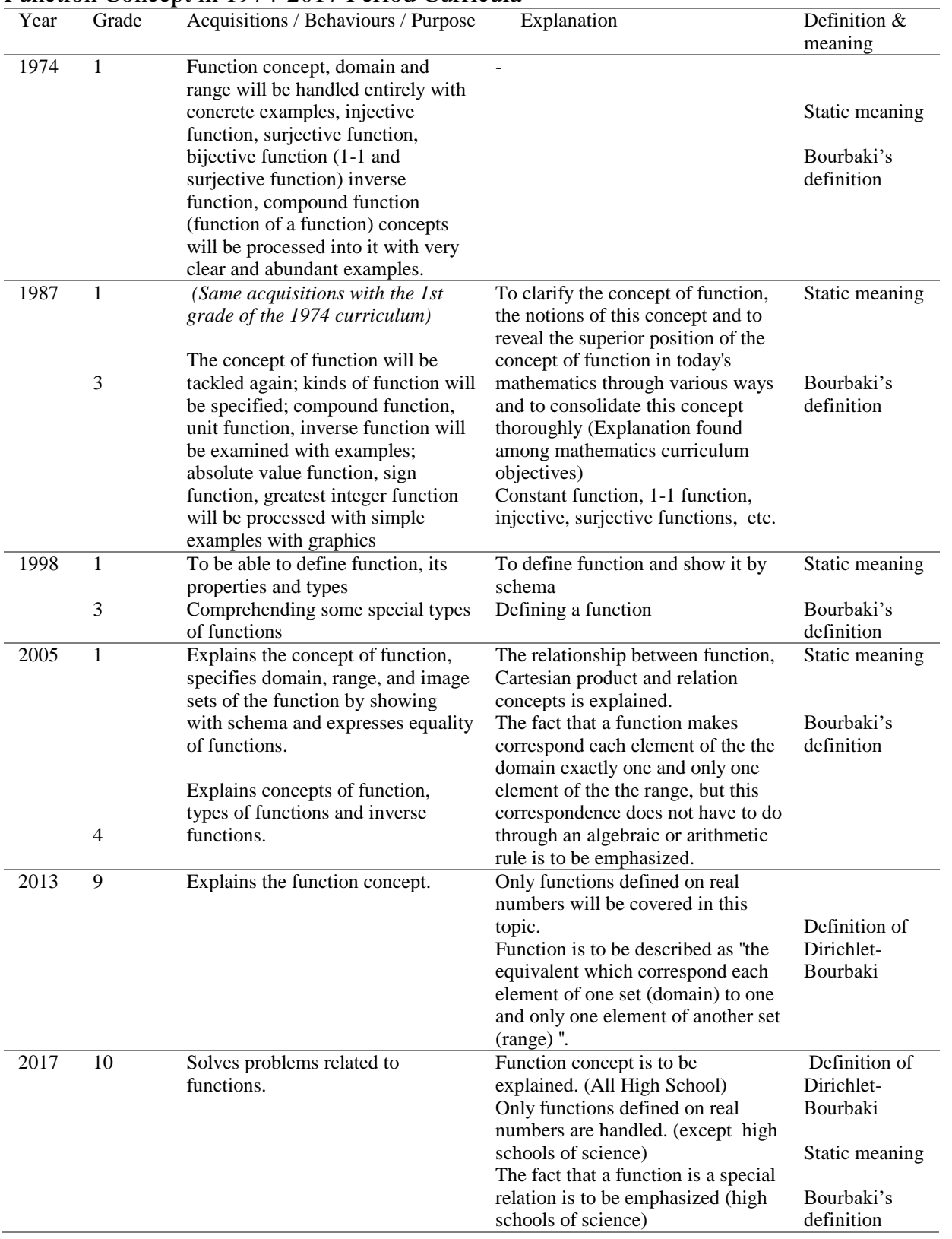

International Journal of Instruction, January2019 • Vol.12, No.1 
With "new mathematics" reform, it was underlined in the objectives section of the curriculum that, it was necessary to review the concepts which feed the function concept in mathematics curricula and it was necessary to identify these concepts in the direction of the new reform (MONE, 1987). In this direction, as seen in table 6, the static Bourbaki definition was used at the beginning of this period. At the end of this period, especially in the 2005 mathematics curricula change, it was emphasized that the function is a special relation by strengthening this static approach. Along with the 2013 mathematics curriculum, the function concept was defined as a relationship which provides certain conditions between two sets in all the schools and function concept was defined without the concept of relation. It was mentioned here that only functions defined on real numbers could be used and thus it is seen that the curriculum developers begun to move away from the Bourbaki's definition and, the Dirichlet-Bourbaki definition seems to be adopted. While the definition of the function concept in the mathematics curriculum of 2017 was protected as the way it was given in the approach of the 2013 curriculum, for high schools of science, it was presented on the basis of the concept of relation. Therefore, the return to the Bourbaki's definition in high schools of science is striking.

The analysis of how the concept took place in textbooks of this period is given in table 7. However, since the introduction of the function concept in the 2017 curriculum moved to the 10th grade and the curriculum was not yet implemented in the 10th grade, there are no textbooks to be studied at the 10th grade level. 
Table 7

Function Concept in 1974-2017 Period Textbooks

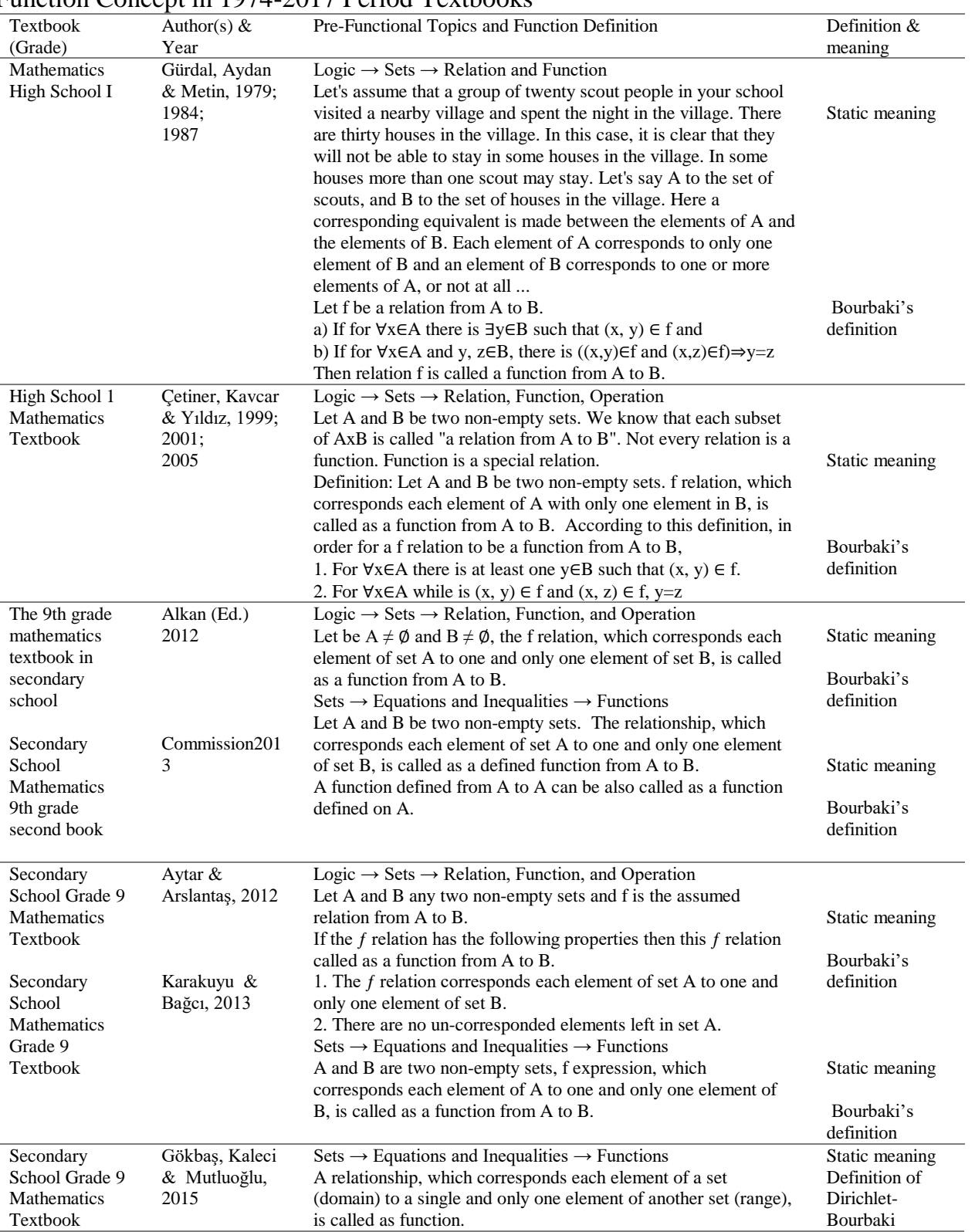

From Table 7 it is clearly understood that at the beginning of this period, function concept was built on the triplet of logic-sets-relation and, Bourbaki's definition was

International Journal of Instruction, January2019 • Vol.12, No.1 
adopted. It was specified that 2013 curriculum only included functions defined on real numbers. In the textbook of 2013 it is understood that the topics that need to be taught before the functions changed as sets, equations and inequalities and, a context was created for defining functions over real numbers. However, it is seen that the definition of this book was not based on real numbers but on arbitrary sets such as A and B. The definition given in the textbook of the 2015 appears to move away, to a certain extent, from Bourbaki's definition and goes towards to the definition of Dirichlet-Bourbaki.

\section{DISCUSSION AND CONCLUSION}

A similarity has been observed between the development of the meaning of the concept for students and the development of mathematical concepts in the historical process (Fried, 2018). In this study, it was revealed that the way the concept of function was included in the curriculum or textbooks was greatly influenced by the historical development process of the concept.

The findings of the study indicate that the function concept passed through three basic periods during the approximately 100-year republican period. Taking into account the dominant approaches, these periods can be called as the Eulerian period, the Dirichletian period and the Bourbakist period. Eulerian period covering the years 1924-1952 concluded with the introduction of function concept into curricula. In this period, there was no definition of function in curricula. However, in the textbooks intuitive definitions were observed as Euler gave them. In this process, function concept was taken into an algebraic context with concepts such as numbers, ratio-proportion and equation. Another feature of this period is that in the textbooks the daily life examples and especially the graphical representation for these intuitive definitions were kept in the front. This finding shows similarities with the study of Hight (1968), as he stated that in the first half of the 20th century, a close definition of the function concept to the Euler's definition was extensively given in the textbooks of America.

In the Dirichletian period covering the years 1952-1974, besides the algebraic context was maintained, the variable concept was often emphasized. Furthermore, in this period's curricula, a great importance was given to the graphical representation of basic functions. In the textbooks, besides the variability feature of functions, the interval concept was included and in parallel with the Dirichlet's definition, the function concept was defined based on the interval concept. However, it is understood that the Dirichletian period soon ended when the first traces of Bourbaki's definition began to appear in 1967. Similarly to this result, Kennedy and Ragan (1969) pointed out that most of the textbooks in America, transitioned from the Euler's definition or from the Dirichlet's definition to the Bourbaki's definition at the end of the 1950s.

It can be said that the Bourbakist period continued its presence from 1974 to the present day. In every curriculum change of this period, although small changes were observed in the definition of function concept, the concept continue to be built on the triplet "logicset-relation" and, the Bourbaki's definition is dominant. In fact, the curriculum of 2013 significantly returned to the context of Eulerian and Dirichletian periods and the function concept has begun to be built on equations and its introduction was limited with 
real functions. Nevertheless, it is seen that, the introductions in the textbooks were systematically constructed through arbitrary set of Bourbakist approaches. Likewise, in the American textbooks of the second half of the 20th century, although the concept was defined in different ways (as sets of ordered pairs, correspondence between variables or elements of two sets, dependent relations, etc.), the effect of Bourbaki's definition was observed in these definitions. (Cha, 1999; Cooney \& Wilson, 1993).

Hight (1968) stated that it is necessary to examine the historical development process of the concept of function and to establish an awareness of its different definitions. It is stated that teachers need to know the different definitions of the function concept, the basic dynamics of these definitions and in which cases they have the advantage or disadvantage (Cha, 1999). Sierpinska (1992), with a didactic point of view, suggested that a similar approach to the Dirichlet's definition should be followed at secondary school level, rather than the Bourbaki's definition. The underlying reason for this can be explained by the fact that the Bourbaki's definition is a complex structure and this complexity comes from the fact that it contains many sub-concepts (Eisenberg, 2002). In support of this, Cha (1999) argued that the Euler's definition at secondary school level is more appropriate because Bourbaki's definition makes it hard to give concrete examples in linking everyday life because of the inclusion of logical items. Liu (2003) stated that the present definition of the concept of function is a consequence of its evolution in its long historical development, and that it is acceptable for students to encounter difficulties in understanding this definition.

Earlier studies showed that the introduction of function concept in curricula and textbooks were close to the Euler's definition at the beginning of the 20th century, Dirichlet's definition started to be used after and, from the 1960s Bourbakist approach has influenced almost every country's mathematics curricula and since the 1990s there was a search for the ways to move away from the Bourbakist approach in teaching mathematics (Cha, 1999; Cooney \& Wilson, 1993; Denbel, 2015; Kennedy \& Ragan, 1969; Sierpinska, 1992; Eisenberg, 2002). The results of this study support well the above studies and despite the chronological differences, it shows that similar definitions of the same cycle took place in Turkey as well.

Since the introduction of didactic transposition theory (Chevallard, 1985), it is well known that transposition of mathematical concepts for teaching purposes is a dynamic, multi-dimensional and problematic process. In the particular case of the function concept, this study also reveals the universality of this process. Contrary to popular opinion, it is understood that mathematics curricula are affected quickly from many universal phenomena, especially from developments in mathematics. On the other hand, this research raises the question of whether changes in mathematics curricula are progressive or cyclical. The fact that Bourbaki's definition requires a high level of abstraction and that students have many difficulties with this definition seems to drive curricula developers of the last 20 years to rediscover the historical algebraic context rather than to develop new approaches. 


\section{RECOMMENDATION}

The results of the present study can be used in examining the transpositions of different concepts in mathematics curricula and textbooks and, offer a holistic view on the definition and the introduction of function concept for curriculum developers.

\section{REFERENCES}

Argün, Z., Arıkan, A., Bulut, S., \& Sriraman, B. (2010). A brief history of mathematics education in Turkey: K-12 mathematics curricula. ZDM, 42(5), 429-441.

Bosch, M., \& Gascón, J. (2006). Twenty-five years of the didactic transposition. ICMI Bulletin, 58, 51-63.

Breslich, E. R. (1932). Measuring the development of functional thinking in algebra. In W. D. Reeve \& V. Sanford (Eds.), The Teaching of Algebra (pp. 93-118). New York, NY: National Council of Teachers of Mathematics, Teachers College, Columbia University.

Cajori, F. (1919). A history of elementary mathematics. New York: Macmillan.

Cha, I. S. (1999). Mathematical and pedagogical discussions of the function concept. Journal of the Korea Society of Mathematical Education Series D: Research in Mathematical Education, 3(1), 35-56.

Chevallard, Y. (1985). La transposition didactique. Du savoir savant au savoir enseigné. Grenoble: La Pensée Sauvage.

Cooney, T. J. \& Wilson, M. R. (1993): Teachers' thinking about functions: historical and research perspectives. In: T. Romberg; E. Fennema \& T. Carpenter (Eds.), Integrating research on the graphical representation of functions. Hillsdale, New Jersey: Erlbaum.

Denbel, D. G. (2015). Functions in the secondary school mathematics curriculum. Journal of Education and Practice, 6(1), 77-81.

Eisenberg, T. (2002). Functions and associated learning difficulties. In D. Tall (Ed.), Advanced mathematical thinking (pp. 140-152). Dordrecht, The Netherlands: Kluwer Academic Publishers.

Erdoğan, A. (2009). Matematiksel nesneler, sorunlu şeyler! Necatibey Eğitim Fakültesi Elektronik Fen ve Matematik Eğitimi Dergisi, 3(1), 156-173.

Even, R. (1993). Subject-matter knowledge and pedagogical content knowledge: Prospective secondary teachers and the function concept. Journal for Research in Mathematics Education, 24(2), 94-116.

Fried, M. N. (2018). History of mathematics, mathematics education, and the liberal arts. In Invited Lectures from the 13th International Congress on Mathematical Education (pp. 85-101). Springer, Cham. 
Güzel, İ., Karataş, İ., \& Çetinkaya, B. (2010). Ortaöğretim matematik öğretim programlarının karşılaştırılması: Türkiye, Almanya ve Kanada. Turkish Journal of Computer and Mathematics Education, 1(3), 309-325.

Hamley, H. R. (1934). Functional thinking. New York, NY: National Council of Teachers of Mathematics, Teachers College, Columbia University.

Hedrick, E. R. (1938). The function concept in elementary teaching and in advanced mathematics. The American Mathematical Monthly, 45(7), 448-455.

Hight, D. W. (1968). Functions: Dependent variables to fickle pickers. The Mathematics Teacher, 61(6), 575-579.

Kline, M. (1972). Mathematical thought from ancient to modern times (Vol. 1). New York: Oxford University Press.

Kleiner, I. (1989). Evolution of the function concept: A brief survey. The College Mathematics Journal, 20(4), 282-300.

Kleiner, I. (1993). Functions: Historical and pedagogical aspects. Science and Education, 2(2), 183-209.

Kennedy, J. \& Ragan, E. (1969): Function. In: National Council of Teachers of Mathematics (Ed.), 31st yearbook: Historical topics for the mathematics classroom (pp. 312-313). Reston, VA: National Council of Teachers of Mathematics.

Liu, P. H. (2003). Do teachers need to incorporate the history of mathematics in their teaching. Mathematics Teacher, 96(6), 416-421.

Lutzen, J. (1983). Euler's vision of a general partial differential calculus for a generalized kind of function. Mathematics Magazine, 56(5), 299-306.

Malik, M. A. (1980). Historical and pedagogical aspects of the definition of function. International Journal of Mathematics Education in Science and Technology, 11, 489492.

Markovits, Z., Eylon, B. S., \& Bruckheimer, M. (1986). Functions today and yesterday. For the learning of mathematics, 6(2), 18-28.

Ministry of National Education (MONE). (1987). Lise matematik programı. Ankara: Milli Eğitim Basımevi.

Merter, F., \& Şan, A. (2012). Lise matematik dersi öğretim programı hakkındaki öğretmen görüşleri. International Jurnal of Social Sciences, 5(7), 483-507.

Merzbach, U. C., \& Boyer, C. B. (2011). A history of mathematics (3 ed.). Hoboken, NJ: Wiley.

Oehrtman, M. C., Carlson, M. P., \& Thompson, P. W. (2008). Foundational reasoning abilities that promote coherence in students' function understanding. In M. P. Carlson \& C. Rasmussen (Eds.), Making the connection: Research and teaching in undergraduate 
mathematics education (pp. 27-42). Washington, DC: Mathematical Association of America.

Ponte, J. P. (1992). The history of the concept of function and some educational implications. The Mathematics Educator, 3(2).

Sajka, M. (2003). A secondary school student's understanding of the concept of function - a case study. Educational Studies in Mathematics, 53, 229-254.

Selden, A., \& Selden, J. (1992). Research perspectives on conceptions of function: Summary and overview. In G. Harel \& E. Dubinsky (Eds.), The concept of function: Aspects of epistemology and pedagogy (pp. 1-16.). Washington, DC: Mathematical Association of America.

Sierpinska, A. (1992). On understanding the notion of function. In G. Harel \& E. Dubinsky (Eds.), The concept of function: Aspects of epistemology and pedagogy (pp. 25-58). Washington, D. C.: Mathematical Association of America.

Siu, M. K. (1994). Concept of function - its history and teaching. In F. Swetz, J. Fauvel, O. Bekken, B. Johansson, \& V. Katz (Eds.), Learn from the masters (pp. 105-121). Washington, DC: Mathematical Association of America.

Tall, D., \& Bakar, M. (1992). Students' mental prototypes for functions and graphs. International Journal of Mathematical Education in Science and Technology, 23(1), 39-50.

Tuncel, T. (2015). Lise matematik dersi öğretim programı ölçme-değerlendirme boyutunun öğretmen görüşlerine göre değerlendirilmesi (Yayınlanmamış doktora tezi). Fırat Üniversitesi.

Usiskin, Z., Peressini, A., Marchisotto, E. A., \& Stanley, D. (2003). Mathematics for high school teachers: an advanced perspective. Upper Saddle River, NJ: Pearson.

Yıldırım, A., \& Şimşek, H. (2011). Sosyal bilimlerde nitel araştırma yöntemleri. Ankara: Seçkin Yayıncılık.

Zeybek, S. (2012). Matematik programlarının gelişimi (1924-2011). Gazi Kitabevi: Ankara. 